\title{
Pengaruh Bahan Ajar Berbasis Pemecahan Masalah terhadap Kemampuan Pemecahan Masalah Matematis
}

\author{
Astri Wahyuni ${ }^{1}$, Lilis Marina Angraini ${ }^{2}$ \\ 1,2 Pendidikan Matematika, Fakultas Keguruan dan Ilmu Pendidikan, Universitas Islam Riau \\ J1. Kaharuddin Nst No.113, Simpang Tiga, Kota Pekanbaru, Indonesia \\ astriwahyuni@edu.uir.ac.id
}

\begin{abstract}
This study aims to see the effect of problem solving based teaching materials on students' mathematical problem solving at Mathematics Education Study Program, FKIP UIR the academic year 2020/2021. This quasi-experiment research was conducted to the 3rd semester students at Math Education FKIP UIR who were selected by saturated sampling technique. This means that all members of the population were chosen as samples of the study (6A and 6B). Data were collected by administering a test. Then, inferential analysis was used to calculate $n$-gain. This study found that a) utilizing problem solving based teaching materials significantly influence students' problem solving ability (Sig $0.006<0.05$ ); b) based on the students' cognitive level, problem solving based materials also significantly influence the students ability (Sig $0.006<0.05$ ); c) there was an interaction between the learning materials and the students' cognitive level with a value of sig $0.045<0.05$. Thus, it was concluded that using problem solving based teaching materials significantly affected the students' mathematical problem solving ability at Mathematics Study Program FKIP UIR.
\end{abstract}

Keywords: Mathematics Learning Materials, Problem Solving Ability

\begin{abstract}
Abstrak
Penelitian ini bertujuan untuk melihat pengaruh bahan ajar berbasis pemecahan masalah terhadap kemampuan pemecahan masalah matematis mahasiswa program studi pendidikan matematika FKIP UIR Tahun Ajaran 2020/2021. Penelitian ini merupakan penelitian kuantitatif dengan metode eksperimen semu (quasi eksperimen), dengan populasi pada penelitian ini adalah seluruh mahasiswa matematika semester 3 (tiga). Kemudian, sampel dipilih menggunakan teknik sampling jenuh dimana kelas 6A dan 6B sebagai sampel penelitian yang artinya seluruh populasi menjadi sampel. Teknik pengumpulan data yang digunakan dengan tes yang telah diuji validitas dan reliabilitasnya. Analisis inferensial digunakan dengan menghitung n-gain. Hasil penelitian ini adalah a) terdapat perbedaan yang signifikan antara mahasiswa yang mengikuti pembelajaran berbantuan bahan ajar dengan pembelajaran tanpa menggunakan bahan ajar secara keseluruhan ( $\operatorname{Sig} 0,006<0,05$ ); b) terdapat perbedaan yang signifikan antara mahasiswa yang mengikuti pembelajaran berbantuan bahan ajar dengan mahasiswa yang mengikuti pembelajaran tanpa menggunakan bahan ajar berdasarkan level kognitif mahasiswa (Sig 0,006 < 0,05); c) terdapat interaksi antara pembelajaran yang digunakan dengan level kognitif mahasiswa dari aspek kemampuan pemecahan masalah matematis (sig $0,045<0,05$ ). Sehingga kesimpulannya bahwa pembelajaran menggunakan bahan ajar berbasis pemecahan masalah secara sigifikan dapat mempengaruhi kemampuan pemecahan masalah matematis pada mahasiswa program studi matematika FKIP UIR.
\end{abstract}

Kata kunci: Bahan Ajar Matematika, Kemampuan Pemecahan Masalah

Copyright (c) 2021 Astri Wahyuni, Lilis Marina Angraini

$\square$ Corresponding author: Astri Wahyuni

Email Address: astriwahyuni@edu.uir.ac.id (Jl. Kaharuddin Nst No.113, Simpang Tiga, Kota Pekanbaru, Indonesia) Received 25 June 2021, Accepted 13 July 2021, Published 02 August 2021

\section{PENDAHULUAN}

Proses pembelajaran yang baik hendaknya bukan hanya fokus pada transfer pengetahuan, melainkan mampu memberikan kegiatan belajar yang melatih kemampuan berpikir mahasiswa sehingga mahasiswa mampu menyelesaikan permasalahan dalam kehidupannya. Akan tetapi pada kenyataannya kemampuan yang sulit dikuasai oleh mahasiswa yaitu kemampuan pemecahan masalah (Lestari, Andinny, \& Mailizar, 2019). Dalam hal ini diperlukan kemampuan pemecahan masalah yang baik, setiap 
Pengaruh Bahan Ajar Berbasis Pemecahan Masalah terhadap Kemampuan Pemecahan Masalah Matematis, Astri Wahyuni,

mahasiswa mesti dilatih dan diajarkan agar dikehidupan sehari-hari mahasiswa bisa menyelesaikan masalahnya. Kemampuan pemecahan masalah bagi siswa sangat berguna tidak di pembelajaran saja, melainkan di kehidupan diluar sekolah juga bisa diterapkan (Novianti, Yuanita, \& Maimunah, 2020). Menurut Lestari, Andinny, \& Mailizar (2019) rendahnya tingkat kemampuan siswa menyelesaikan permasalahan yang berkaitan dengan kehidupan diluar sekolah merupakan salah satu kendala utama dalam pembelajaran. Pemecahan masalah memiliki peranan penting di dunia pendidikan, khususnya dibidang matematika (NTCM, 2010). Pemecahan masalah merupakan proses dari pembelajaran sehingga peserta didik mendapatkan pengalaman menggunakan ilmu yang sudah dikuasai (Hadi \& Radiyatul, 2014). Pemecahan masalah adalah fokus dari pembelajaran pada matematika sekolah (Ali, Hukamdad, Akhter, \& Khan, 2010; Caballero, Blanco, \& Guerro, 2011; Karatas \& Baki, 2013). Oleh karena itu, sejak dini sudah diajarkan kepada mahasiswa agar penting untuk mengembangkan kemampuan dari pemecahan masalah (Arslan, 2010). Menurut Polya, langkah pemecahan masalah terdiri dari mengetahui masalah, membuat rencana penyelesaian masalahnya, menyelesaikan rencana yang telah dibuat, dan pengecekan apa yang telah dikerjakan (Polya, 1985; Fatmawati, Mardiyana, \& Triyanto, 2014).

Kemampuan pemecahan masalah diartikan sebagai kemampuan yang ada pada diri pada saat mencari dan memunculkan strategi yang kreatif untuk menemukan solusi dari permasalahan yang ingin diselesaikan (Csapó \& Funke, 2017). Pemecahan masalah matematis adalah kemampuan kognitif yang dapat membantu siswa menyelesaikan persoalan matematika dengan baik (Amam, 2017). Keterampilan yang harus mahasiswa kuasai ketika akan memecahkan masalah matematika yaitu mengartikan soal, menggunakan strategi, dan menyelesaikan operasi bilangan (Runtukahu \& Kandou, 2014).

Matematika merupakan hal yang sulit untuk dipelajari bagi sebagian orang (Oktaviani, Dewi, \& Kiswoyo, 2019). Kesulitan mahasiswa dalam menyelesaikan masalah matematika yaitu ketika tidak mampu menyelesaikan masalah matematika ketika terdapat kesalahan. Dampak negatif dari kesulitan belajar yaitu prestasi dari mahasiswa itu sendiri, jika mahasiswa ingin mendapatkan prestasi yang baik maka perlakuan dan usaha mahasiswa harus ditingkatkan lagi. Menurut Ixganda \& Suwahyo (2015) gejala kesulitan belajar mahasiswa yaitu prestasi yang menurun, tidak seimbang antara hasil dengan usaha, lambat dalam mengerjakan tugas, kurang wajar dalam sikapnya, tingkah laku yang tidak sopan kepada orang lain. Salah satu kesulitan mahasiswa dalam mempelajari matematika yaitu peserta didik tidak bisa menyelesaikan soal matematika, dengan soal pemecahan masalah merupakan tipe soal yang sulit diselesaikan. Dengan mengetahui kesalahan penyelesaian permasalahan matematika, maka dapat dicari kesulitan ketika belajar matematika.

Berdasarkan hasil latihan soal pemecahan masalah yang di ujikan pada mahasiswa kelas $6 \mathrm{~A}$ dan $6 \mathrm{~B}$ ketika pembelajaran analisis komplek, dapat dilihat informasi bahwa nilai dari mahasiswa sangat rendah dengan hasil latihan soal pada tabel ini. 
Tabel 1. Hasil Latihan Soal Kelas 6A dan 6B

\begin{tabular}{|c|c|}
\hline Kelas & Rata-Rata Nilai \\
\hline $6 \mathrm{~A}$ & 45 \\
\hline $6 \mathrm{~B}$ & 41 \\
\hline
\end{tabular}

Penyebab nilai rendah pada dua kelas ini dikarenakan mahasiswa belum terbiasa menyelesaikan soal tersebut dan memang belum pernah diberi bahan ajar atau pun materi yang di dalamnya sudah didesain sedemikian rupa supaya bisa menaikkan kemampuan pemecahan masalah mahasiswa. Penyelesaian terbaik yaitu membantu mengasah kemampuan pemecahan masalah dari mahasiswa melalui pemberian bahan ajar membiasakan menyelesaikan soal pemecahan masalah. Sehingga peneliti merasa perlu memberikan bahan ajar matematika kepada mahasiswa yang materinya telah sesuai dengan kebutuhan kelas dan soal-soal yang diberikan berbasis pemecahan masalah. Menurut Sanjaya (2007) beberapa kelebihan pembelajaran berbasis masalah yaitu meningkatkan aktivitas pembelajaran mahasiswa dalam pemecahan masalah, dan mendapatkan ilmu baru bagi mahasiswa supaya dapat memecahkan menyelesaikan soal dengan kemampuan masalah. Penelitian dengan menggunakan kemampuan pemecahan matematis sjuga dilakukan oleh Ayubi, Erwanudin, \& Bernard (2018) dengan hasil akhir bahwa kemampuan pemecahan matematis lebih baik daripada pembelajaran biasa. Dengan bahan ajar yang sudah dilakukan uji validasi oleh ahli materi yaitu dua dosen Pendidikan Matematika, maka bahan ajar ini siap untuk diujikan ke mahasiswa. Sementara itu, tujuan penelitian ini dari penelitian ini: 1) melihat perbedaan kemampuan pemecahan masalah matematis secara keseluruhan berdasarkan level kognitif mahasiswa (tinggi, sedang, rendah) antara mahasiswa yang memperoleh bahan ajar berbasis pemecahan masalah matematis (kelas eksperimen) dengan mahasiswa yang memperoleh pembelajaran konvensional (kelas kontrol); 2) untuk melihat perbedaan kemampuan pemecahan masalah matematis antara mahasiswa yang memperoleh bahan ajar berbasis pemecahan masalah matematis (kelas eksperimen) dengan mahasiswa yang memperoleh pembelajaran konvensional (kelas kontrol) berdasarkan level kognitif mahasiswa (tinggi, sedang, rendah); 3) untuk melihat interaksi antara pembelajaran yang digunakan dan level kognitif mahasiswa terhadap pencapaian kemampuan pemecahan masalah matematis mahasiswa.

\section{METODE}

Penelitian ini mengkaji pembelajaran dengan bahan ajar berbasis pemecahan masalah matematis dan pengaruhnya terhadap kemampuan pemecahan masalah matematis, berpikir kritis matematis serta disposisi berpikir kritis matematis. (Sugiyono, 2010) mengatakan penelitian eksperimen merupakan metode penelitian yang dilakukan untuk mencari pengaruh tertentu. Penelitian melibatkan dua kelas, yaitu kelas eksperimen dan kelas kontrol. Kelas eksperimen adalah kelas yang memperoleh pembelajaran dengan bahan ajar berbasis pemecahan masalah matematis dan kelas kontrol adalah kelas yang memperoleh pembelajaran konvensional. 
Pengaruh Bahan Ajar Berbasis Pemecahan Masalah terhadap Kemampuan Pemecahan Masalah Matematis, Astri Wahyuni, Lilis Marina Angraini

Peneliti menggunakan quasi eksperiment nonequivalen control group sebagai desain penelitian, karena mahasiswa yang menjadi responden akan menggunakan kelas yang ada dan tidak akan mengambil mahasiswa secara acak. (Ruseffendi, 2003) menggambarkan diagram desain penelitiannya yaitu:

\begin{tabular}{|l|l|l|}
\hline $\mathrm{O}$ & $\mathrm{X}$ & $\mathrm{O}$ \\
\hline $\mathrm{O}$ & & $\mathrm{O}$ \\
\hline
\end{tabular}

Keterangan:

$\mathrm{O}=$ Pretest dan posttest

$\mathrm{X}=$ Pembelajaran menggunakan bahan ajar matematika

Penelitian ini juga dilakukan dengan pengujian hasil dari interaksi pembelajaran dengan kategori level kognitif mahasiswa, dengan subjek pada penelitian yang akan diuji yakni mahasiswa Program Studi Pendidikan Matematika di Universitas Islam Riau yang berasal dari semester VI pada tahun ajaran 2020/2021. Data penelitian yang berkaitan akan dikumpulkan melalui tes (pretest dan posttest). Analisis data dilakukan empat pengujian, yakni Uji normalitas, Uji Homogenitas, Uji Anova 2 jalur dan Uji lanjut Scheffe. Untuk kategori kemampuan pemecahan masalah matematis mahasiswa akan disesuaikan dengan kebutuhannya, sehingga peneliti menentukan anggota sampel mana yang mempunyai kemampuan rendah, sedang, hingga tinggi akan didasarkan pada hasil uji coba kemampuan matematis dari subjek penelitian yakni mahasiswa. Pengkategorian kemampuan pemecahan masalah matematis mahasiswa dibagi menjadi kelompok tinggi, sedang dan rendah, sedangkan kriteria pencapaian kemampuan pemecahan masalah dijelaskan pada tabel dibawah ini:

Tabel 2. Kategori Pencapaian Kemampuan Pemecahan Masalah Matematis

\begin{tabular}{|c|c|}
\hline Skor & Kategori \\
\hline$X<30 \%$ & Rendah \\
\hline $30 \% \leq X<70 \%$ & Sedang \\
\hline$X \geq 70 \%$ & Tinggi \\
\hline
\end{tabular}

\section{HASIL DAN DISKUSI}

\section{Deskriptif Kemampuan Pemecahan Masalah}

Instrumen kemampuan pemecahan masalah matematis berbentuk tes. Diketahui bahwa terdapat 2 kelas yang digunakan untuk mengukur kemampuan pemecahan masalah mahasiswa yang terdiri dari 29 orang di kelas sksperimen dan 33 orang pada kelas kontrol. Berdasarkan hasil hitung dengan menggunakan program SPSS diperoleh deskiptif variabelnya yaitu sebagai berikut: 
Tabel 3. Statistik Kemampuan Pemecahan Masalah

\begin{tabular}{|c|c|c|c|c|c|}
\hline & & $\begin{array}{c}\text { Level } \\
\text { Kognitif }\end{array}$ & Kelompok & $\begin{array}{c}\text { Pemecahan } \\
\text { Masalah } \\
\text { Pretest } \\
\end{array}$ & $\begin{array}{c}\text { Pemecahan } \\
\text { Masalah } \\
\text { Posttest } \\
\end{array}$ \\
\hline$N$ & Valid & 62 & 62 & 62 & 62 \\
\hline 10 & Missing & 0 & 0 & 0 & 0 \\
\hline & & 1.85 & 1.53 & 49.9032 & 68.7581 \\
\hline & & 2.00 & 2.00 & 46.0000 & 67.0000 \\
\hline & eviation & .743 & .503 & 10.50638 & 14.51024 \\
\hline & num & 1 & 1 & 25.00 & 35.00 \\
\hline & num & 3 & 2 & 77.00 & 100.00 \\
\hline $\mathrm{Su}$ & & 115 & 95 & 3094.00 & 4263.00 \\
\hline
\end{tabular}

Dari hasil diatas dapat dilihat bahwa nilai maksimum dari hasil kemampuan pemecahan masalah pretest sebesar 77, nilai minimum sebesar 25 dengan rata-rata mencapai 49,9032. Untuk nilai maksimum kemampuan pemecahan masalah posttest sebesar 100, nilai minimum sebesar 35 dengan rata-rata sebesar 68,7581 dan standart deviasi sebesar 14,51024. Sehingga, terjadi peningkatan kemampuan pada pemecahan masalah matematis apabila dilihat dari hasil pretest dan postest. Adapun perhitungan kategorisasi variabel Level Kognitif untuk kemampuan pemecahan masalah yakni:

Tabel 4. Kategorisasi Variabel Level Kognitif untuk Kemampuan Pemecahan Masalah

\begin{tabular}{|c|c|}
\hline Skor & Kategori \\
\hline $\mathrm{X}<30 \%$ & Rendah \\
\hline $30 \% \leq \mathrm{X}<70 \%$ & Sedang \\
\hline $\mathrm{X} \geq 70 \%$ & Tinggi \\
\hline
\end{tabular}

Dengan hasil sebagai berikut:

Tabel 5. Level Kognitif Mahasiswa

\begin{tabular}{|l|l|r|r|r|r|}
\hline \multicolumn{2}{|c|}{} & Frequency & Percent & $\begin{array}{c}\text { Valid } \\
\text { Percent }\end{array}$ & $\begin{array}{c}\text { Cumulative } \\
\text { Percent }\end{array}$ \\
\hline \multirow{4}{*}{ Valid } & Rendah & 22 & 35.5 & 35.5 & 35.5 \\
\cline { 2 - 6 } & Sedang & 27 & 43.5 & 43.5 & 79.0 \\
\cline { 2 - 6 } & Tinggi & 13 & 21.0 & 21.0 & 100.0 \\
\cline { 2 - 6 } & Total & 62 & 100.0 & 100.0 & \\
\hline
\end{tabular}

Dari tabel diatas, sebagian besar level kognitif mahasiswa berada pada kategori sedang yaitu sebanyak 27 mahasiswa atau 43,5\% sedangkan untuk kategori level kognitif rendah sebanyak 22 mahasiswa atau 35,5\% dan untuk kategori level kognitif tinggi sebanyak 13 mahasiswa atau $21 \%$ yang berasal dari kedua kelompok kelas eksperimen dan kelas kontrol. Sehingga sebaran level kognitif siswa sudah ideal dan heterogen sehingga baik digunakan sebagai sampel penelitian. 
Pengaruh Bahan Ajar Berbasis Pemecahan Masalah terhadap Kemampuan Pemecahan Masalah Matematis, Astri Wahyuni, Lilis Marina Angraini

\section{Analisis Inferensial}

\section{Uji Normalitas}

Pengujian ini menggunakan kriteria yakni nilai probabilitas (sig.) lebih besar dari $\alpha=0,05$ maka H0 diterima, sedangkan untuk kondisis lainnya $\mathrm{H0}$ akan ditolak. Hasil perhitungan uji normalitas kemampuan Pemecahan Masalah sudah disusun pada Tabel dibawah:

Tabel 6. One-Sample Kolmogorov-Smirnov Test

\begin{tabular}{|c|c|c|c|}
\hline & Eksperimen & Kontrol \\
\hline \multicolumn{2}{|l|}{$\mathrm{N}$} & 29 & 33 \\
\hline \multirow{2}{*}{$\begin{array}{l}\text { Normal } \\
\text { Parameters }{ }^{\mathrm{a}, \mathrm{b}}\end{array}$} & Mean & .5746 & .301 \\
\hline & Std. Deviation & .20893 & .29126 \\
\hline \multirow{3}{*}{$\begin{array}{l}\text { Most Extreme } \\
\text { Differences }\end{array}$} & Absolute & .100 & .156 \\
\hline & Positive & .083 & .156 \\
\hline & Negative & -.100 & -.120 \\
\hline \multicolumn{2}{|c|}{ Kolmogorov-Smirnov Z } & .537 & .898 \\
\hline \multicolumn{2}{|c|}{ Asymp. Sig. (2-tailed) } & .935 & .396 \\
\hline
\end{tabular}

a. Test distribution is Normal.

b. Calculated from data.

Berdasarkan tabel 6 di atas, diperoleh nilai Asymp. Sig. (2-tailed) untuk kelompok eksperimen sebesar 0,935>0,05 dan kelompok kontrol sebesar 0,396>0,05. Sehingga pemecahan masalah mahasiswa pada kedua kelas tersebut berdistribusi normal pada taraf signifikansi $\alpha=0,05$.

\section{Uji Homogenitas}

Uji homogenitas pada kemampuan pemecahan masalah matematis semua mahasiswa digunakan menggunakan uji Levene.

Tabel 7. Test of Homogeneity of Variances Pemecahan Masalah Matematis

\begin{tabular}{|c|c|c|c|}
\hline Levene Statistic & df1 & df2 & df3 \\
\hline 1.746 & 1 & 60 & .191 \\
\hline
\end{tabular}

Dari hasil diatas, dapat dilihat bahwa nilai Lavene Statistic sebesar 1.746 dengan nilai signifikansi mencapai 0,191 > 0,05. Maka kedua kelompok pembelajaran memiliki varian yang sama dan dapat dilanjutkan pada tahap berikutnya.

\section{Uji Hipotesis}

Hipotesis 1: Terdapat perbedaan kemampuan pemecahan masalah matematis antara mahasiswa yang memperoleh bahan ajar berbasis pemecahan masalah matematis (Kelas Eksperimen) dan mahasiswa yang memperoleh pembelajaran konvensional (Kelas Kontrol) secara keseluruhan dan sesuai dengan level Kognitif mahasiswa. 
Tabel 8. Tests of Between-Subjects Effects

Dependent Variable: Kemampuan Pemecahan Masalah

\begin{tabular}{|l|r|c|r|r|r|}
\hline Source & $\begin{array}{l}\text { Type III Sum } \\
\text { of Squares }\end{array}$ & df & $\begin{array}{l}\text { Mean } \\
\text { Square }\end{array}$ & F & Sig. \\
\hline Corrected Model & $4.442^{\mathrm{a}}$ & \multicolumn{1}{l|}{5} & .888 & 77.666 & .000 \\
\hline Intercept & 11.117 & 1 & 11.117 & 971.799 & .000 \\
\hline Level Kognitif_- & 2.831 & 2 & 1.416 & 123.746 & .000 \\
\hline Kelompok & .094 & 1 & .094 & 8.249 & .006 \\
\hline $\begin{array}{l}\text { Level Kognitif* } \\
\text { Kelompok }\end{array}$ & .075 & 2 & .037 & 3.269 & .045 \\
\hline Error & .641 & 56 & .011 & & \\
\hline Total & 16.522 & 62 & & & \\
\hline Corrected Total & 5.083 & 61 & & & \\
\hline
\end{tabular}

a. $\quad$ R Squared $=.874($ adjusted R Squared $=.863)$

Kriteria pengujian adalah tolak H0, jika Asymp. $\operatorname{Sig}(1$-tailed) $<\alpha=0,05$. Setelah dilakukan perhitungan ANOVA dua jalur yang hasilnya dapat dilihat pada tabel. Diperoleh nilai sig. (1-tailed) sebesar 0,006 $<$ 0,05. Karena itu, hasilnya hipotesis nol ditolak, artinya Pencapaian Kemampuan pemecahan masalah mahasiswa yang memperoleh bahan ajar berbasis pemecahan masalah (Kelas Eksperimen) lebih baik daripada mahasiswa yang memperoleh pembelajaran konvensional (Kelas Kontrol) berdasarkan Level kognitif Mahasiswa.

Hipotesis 2: Terdapat Interaksi antara Pembelajaran pembelajaran yang digunakan dan level Kognitif mahasiswa terhadap pencapaian Kemampuan Pemecahan Masalah Matematis Mahasiswa.

Dari tabel di atas, terlihat signifikansi untuk interaksi antara metode pembelajaran dan kategori kemampuan pemecahan masalah sebesar 0,045 $<0,05$ yang artinya terdapat interaksi antara pembelajaran yang digunakan dan Level Kognitif terhadap pencapaian kemampuan pemecahan masalah mahasiswa.

\section{Uji Lanjut}

Tahap selanjutnya adalah peneliti melakkan uji Scheffe pada pos Hoc yang bertujuan untuk melihat perbedaan dari setiap kelas pada tiap kelompok tertentu.

Tabel 9. Multiple Comparisons

Dependent Variable: Pemecahan_Masalah

Scheffe

\begin{tabular}{|c|c|c|c|c|c|c|}
\hline \multirow{2}{*}{$\begin{array}{l}\text { (I) Level } \\
\text { Kognintif }\end{array}$} & \multirow{2}{*}{$\begin{array}{r}\text { (J) Level } \\
\text { Kognintif }\end{array}$} & \multirow{2}{*}{$\begin{array}{l}\text { Mean } \\
\text { Difference (I-J) }\end{array}$} & \multirow[t]{2}{*}{ Std. Error } & \multirow[t]{2}{*}{ Sig. } & \multicolumn{2}{|c|}{ 95\% Confidence Interval } \\
\hline & & & & & Lower Bound & Upper Bound \\
\hline \multirow{2}{*}{ Renda } & Sedang & $-.343182026^{*}$ & 54 & .000 & -.42043 & -.265 \\
\hline & & & & .000 & & -.6 \\
\hline \multirow{2}{*}{ Sedang } & & & .030 & .000 & .265 & \\
\hline & & $-.367730707^{*}$ & & .000 & -.4585 & -.27 \\
\hline \multirow{2}{*}{ Tinggi } & & & .037 & .00 & .61682 & 2996 \\
\hline & $\overline{\mathrm{Sec}}$ & $.367730707^{*}$ & .0361063609 & .000 & .276933996 & .458527417 \\
\hline
\end{tabular}

Based on observed means.

The error term is Mean Square $($ Error $)=.11$.

*. The mean difference is significant at the 0.05 level. 
Pengaruh Bahan Ajar Berbasis Pemecahan Masalah terhadap Kemampuan Pemecahan Masalah Matematis, Astri Wahyuni, Lilis Marina Angraini

Dari tabel 9, terdapat perbedaan antara kelas eksperimen dan kelas kontrol pada peningkatan kemampuan masalah dengan kelompok pada satu kelas nilai sig. $<0,05$. Selain itu terdapat perbedaan kemampuan pemecahan masalah pada semua kelompok di dua kelas yang diteliti dengan nilai sig. $<0,05$.

\section{Diskusi}

Dari penelitian yang sudah dilakukan, diketahui bahwa nilai maksimum dari hasil kemampuan pemecahan masalah pretest sebesar 77, nilai minimum sebesar 25 dengan nilai rata-rata yakni 49,9032. Untuk nilai maksimum kemampuan pemecahan masalah posttest sebesar 100, nilai minimum sebesar 35 dengan rata-rata sebesar 68,7581 dan standart deviasi sebesar 14,51024. Sehingga terjadi peningkatan kemampuan pemecahan masalah mahasiswa pada kedua kelas yang diteliti. Peningkatan kemampuan pemecahan masalah matematis mahasiswa ini disebabkan oleh banyak hal diantaranya adalah karena mahasiswa antusias dalam mengikuti pembelajaran di kelas.

Pandemi Covid-19 membuat pembelajaran tidak dilakukan di sekolah, tetapi dilakukan secara daring sehingga mulai dari awal hingga akhir pertemuan berbantuan aplikasi google meeting, google classroom, dan Whatsapp. Secara garis besar pelaksanaan pembelajaran di kelas eksperimen cenderung lancar dan mampu membuat antusias mahasiswa dalam belajar.

Pada kelas eksprerimen mahasiswa difasilitasi bahan ajar matematika yang digunakan pada saat pembelajaran telah dirancang sedemikian rupa, yaitu dengan bahan ajar matematis yang dirancang berbasis masalah. Dalam bahan ajar tersebut sudah terdapat langkah-langkah pemecahan masalah matematis sehingga memudahkan mahasiswa dalam memecahkan masalah. Selain itu, dosen harus mampu mengatur kelas menjadi lebih santai dan menyenangkan dengan adanya waktu break dan bercanda ringan. Hal ini dilakukan agar mahasiswa tidak bosan karena pembelajaran daring yang hanya menatap laptop tanpa aktivitas lain biasanya membosankan bagi mahasiswa. Sedangkan pada kelas kontrol mahasiswa belajar secara konvensional di mana dosen menjelaskan materi seperti bisa dengan memanfaatkan sajian materi dari buku, melakukan tanya jawab dan latihan soal rutin, di sini mahasiswa terlihat cenderung mudah bosan pada saat pembelajaran walaupun sudah dilakukan break dan bercanda ringan seperti kelas eksperimen. Hal ini terlihat dari hasil penelitian yang terlihat bahwa kemampuan pemecahan masalah dari mahasiswa yang memperoleh bahan ajar berbasis pemecahan masalah (kelas eksperimen) lebih baik daripada mahasiswa yang memperoleh pembelajaran konvensional (kelas kontrol) secara keseluruhan dan berdasarkan level kognitif mahasiswa. (Sumartini, 2015) menyatakan bahwa pemecahan masalah merupakan suatu proses untuk mengatasi kesulitan-kesulitan yang dihadapi untuk mencapai tujuan yang diharapkan. Maka mahasiswa telah mampu mengatasi masalah dan kesulitannya selama belajar.

Berdasarkan hasil penelitian maka dapat disimpulkan terdapat interaksi pada pembelajaran yang digunakan dengan level kognitif mahasiswa dengan pencapaian kemampuan pemecahan masalah matematis mahasiswa. Pada uji lanjutan diperoleh informasi bahwa terdapat perbedaan kemampuan pemecahan masalah matematis mahasiswa antara kelompok tinggi, sedang, dan rendah antara kelas eksperimen terhadap kelas kontrol. Sehingga interaksi antara pembelajaran (menggunakan bahan ajar dan 
konvensional) dengan level kognitif (tinggi, sedang dan rendah) mahasiswa memberikan pengaruh yang signifikan terhadap kemampuan pemecahan masalah matematis mahasiswa.

\section{KESIMPULAN}

Dari hasil penelitian yang telah dilakukan, peneliti menyimpulkan: 1) Terdapat perbedaan kemampuan pemecahan masalah matematis antara mahasiswa yang memperoleh bahan ajar berbasis pemecahan masalah matematis dan mahasiswa yang memperoleh pembelajaran konvensional secara keseluruhan. 2) Terdapat perbedaan kemampuan pemecahan masalah matematis antara mahasiswa yang memperoleh bahan ajar berbasis pemecahan masalah matematis dan mahasiswa yang memperoleh pembelajaran konvensional berdasarkan level kognitif mahasiswa (tinggi, sedang, rendah). 3) Terdapat interaksi antara pembelajaran yang digunakan dan level kognitif mahasiswa terhadap pencapaian kemampuan pemecahan masalah matematis mahasiswa. Sehingga dapat disimpulkan secara umum bahwa penggunaan bahan ajar matematika berbasis pemecahan masalah berpengaruh signifikan terhadap kemampampuan pemecahan masalah mahasiswa prodi Pendidikan matematika FKIP UIR.

\section{UCAPAN TERIMA KASIH}

Ucapan terimakasih kami berikan kepada Lembaga Penelitian dan Pengabdian kepada Masyarakat Universitas Islam Riau yang telah mendanai penelitian ini. Kami ucapkan terimakasih juga kepada seluruh validator penelitian dan dosen pengampu mata kuliah Analisis Komplek yang telah membantu untuk mensukseskan penelitian ini.

\section{REFERENSI}

Ali, R., Hukamdad, D., Akhter, A., \& Khan, A. (2010). Effect of Using Problem Solving Method in Teaching Mathematics on the Achievement of Mathematics Students. Asian Social Science, 6(2), 67-72. https://doi.org/10.5539/ass.v6n2p67

Amam, A. (2017). Penilaian Kemampuan Pemecahan Masalah Matematis Siswa SMP. Jurnal Teori Dan Riset Matematika (Teorema), 2(1), 39-46. https://doi.org/10.25157/.v2i1.765

Arslan, E. (2010). Analysis of communication skill and interpersonal problem solving in preschool trainees. Social Behavior and Personality, 38(4), 530. https://doi.org/10.2224/sbp.2010.38.4.523

Ayubi, I. I. Al, Erwanudin, \& Bernard, M. (2018). Pengaruh Pembelajaran Berbasis Masalah Terhadap Kemampuan Pemecahan Masalah Matematis Siswa Smp. JPMI (Jurnal Pembelajaran Matematika Inovatif), 1(3), 355-360. https://doi.org/10.22460/jpmi.v1i3.p445-452

Caballero, A., Blanco, L. J., \& Guerrero, E. (2011). Problem solving and emotional education in initial primary teacher education. Eurasia Journal of Mathematics, Science and Technology Education, 7(4), 281-292. https://doi.org/10.12973/ejmste/75206

Csapó, B., \& Funke, J. (2017). The Nature of Problem Solving: Inspire 20th century. 
Pengaruh Bahan Ajar Berbasis Pemecahan Masalah terhadap Kemampuan Pemecahan Masalah Matematis, Astri Wahyuni,

Fatmawati, H., Mardiyana, \& Triyanto. (2014). Analisis Berpikir Kritis Siswa Dalam Pemecahan Masalah Matematika Berdasarkan Polya Pada Bahasan Persamaan Kuadrat. 2(9), 899-910. https://doi.org/10.31227/osf.io/wsza9

Hadi, S., \& Radiyatul, R. (2014). Metode Pemecahan Masalah Menurut Polya untuk Mengembangkan Kemampuan Siswa dalam Pemecahan Masalah Matematis di Sekolah Menengah Pertama. EDUMAT: Jurnal Pendidikan Matematika, 2(1), 53-61. https://doi.org/10.20527/edumat.v2i1.603

Ixganda, O., \& Suwahyo. (2015). Analisis Deskriptif Faktor Penyebab Kesulitan Belajar Pada Mata Pelajaran Chassis Dan Pemindah Daya Siswa Kelas XI Program Keahlian Teknik Kendaraan Ringan. Jurnal Pendidikan Teknik Mesin Unnes, 15(2), 103-108.

Karatas, I., \& Baki, A. (2013). The Effect of Learning Environments Based on Problem Solving on Students 'Achievements of Problem Solving. International Electronic Journal of Elementary Education, 5(3), 249-267.

Lestari, I., Andinny, Y., \& Mailizar, M. (2019). Pengaruh Model Pembelajaran Situation Based Learning dan Kemandirian Belajar Terhadap Kemampuan Pemecahan Masalah Matematis. JNPM (Jurnal Nasional Pendidikan Matematika), 3(1), 95. https://doi.org/10.33603/jnpm.v3i1.1748

Mathematics, N. C. of T. of. (2010). Principles and standards for school mathematics. VA: NCTM.

Novianti, E., Yuanita, P., \& Maimunah. (2020). Pembelajaran Berbasis Masalah dalam Meningkatkan Kemampuan Pemecahan Masalah Matematika. Journal of Education and Learning Mathematics Research (JELMaR), 1(1), 65-73. https://doi.org/10.37303/jelmar.v1i1.12

Oktaviani, T., Sulistya Dewi, E. R., \& Kiswoyo. (2019). Penerapan Pembelajaran Aktif Dengan Metode Permainan Bingo Untuk Meningkatkan Hasil Belajar Matematika. Mimbar Ilmu, 24(1), 47-52. https://doi.org/10.23887/mi.v24i1.17409

Runtukahu, T., \& Kandou, S. (2014). Pembelajaran Matematika Dasar Bagi Anak Berkesulitan Belajar. Yogyakarta: Ar-Ruzz Media.

Ruseffendi, E. T. (2003). Dasar-dasar Penelitian Pendidikan dan Bidang Non Ekasakta Lainnya. Bandung: Tarsito.

Sanjaya, W. (2007). Strategi Pembelajaran Berorientasi Standar Proses Pendidikan. Jakarta: Kencana. Sugiyono. (2010). Metode Penelitian Pendidikan. Bandung: Alfabeta.

Sumartini, T. S. (2015). Peningkatan Kemampuan Penalaran Matematis Siswa melalui Pembelajaran Berbasis Masalah. Mosharafa: Jurnal Pendidikan Matematika, 5(1), 1-10. 